NGUYÊN THI MY, Linh

DOI: 10.15170/DIKE.2018.02.02.05

PhD-hallgató, PTE ÁJK

tanársegéd, Can Tho Egyetem, Vietnám

\title{
The Development of Matrimonial Property Law in Vietnam
}

This article analyzes the development of the law on matrimonial property from ancient to modern times in Vietnam. It is clear that the development of the marriage law on property changes in each period of history. The article is not merely an analysis of marital property law in Vietnam but also a comparison with the laws of some countries such as China, France and Hungary. By reviewing and comparing, the article draws on legislative experiences on the regulations of the matrimonial property regime in Vietnam.

Keywords: matrimonial property law, Vietnam, European impact

It can be said that the regulations on matrinmonial property law between husband and wife are subject to change from time to time. In particular, from a historical point of view, Vietnam was a nation invaded and colonized by many empires. Thus, more or less Vietnamese laws are influenced by the laws of the imperial countries that invaded Vietnam. Specifically, the development of the matrimonial property law can be divided into three main stages to study.

\section{The matrimonial property law from the formation of the state to the feudal period in Vietnam (around $258 \mathrm{BC}^{1}$ to 1858)}

Since the sources of information in the early stages of state formation were sought, the search for the origin of family organization was mainly based on legends, folklore stories passed on from Vietnam's ancestors to descendants. The descendants later reproduced the narratives through archaeological evidence, both domestically and internationally (mainly from China).

So far, researchers have not found traces to confirm that the Hung Vuong era has written and the source of law was mostly customary. ${ }^{2}$ In terms of family origins, "Van Lang was referred to as a first institution in Vietnam. Although the organizational model was still simple, Van Lang was divided into 15 sets". $^{3}$ In general, the patriarchal traditions have been established int the period of the Hung Kings. A typical example was the King Hung's succession of the king to the son for the country after marriage.

\footnotetext{
1 This time is taken by VăN, Thời đại Hùng Vương 53.

2 ĐINH GIA, Sơ thảo lịch sử nhà nước và pháp quyền Việt Nam 36.

${ }^{3}$ PHAN HuY, Lịch triều hiến chương đại chí 23
} 
Society recognized the monogamous marriage and the patriarchal form of marriage through wife moving to her husband's home after marriage. ${ }^{4}$ However, there was still the equality between husband and wife, because private ownership, though born, was not strong enough to impact family and society. "In fact, the land in this period remained in the public domain." Thus, this shows that the wife was still equal to her husband rather than in the feudal period.

From 179 BC to $1858^{6}$, Vietnam was invaded and colonized by Chinese feudal dynasties. Thus, Vietnamese law at this time was greatly affected by Chinese feudal law through the dynasties they ruled and colonized. The Hong Duc Code $(1470$ - 1497) and the Gia Long Code (1812) were the two most frequently mentioned laws in this period. It can be said that the Hong Duc Code ${ }^{7}$ was the first law to set the law of Vietnam in general, as well as the matrimonial property relationship between husband and wife. Although there were many limitations, the Hong Duc Code was still appreciated for the progressive ideals of the matrimonial property relationship between spouses. For instance, Article 374 of the Hong Duc Code started that when a husband dies, he would leave two types of property: the husband's separate property and the common property of the husband and wife. The husband's separate property would be left to the husband's family management. For the common property of the husband and wife, the wife was entitled to a part of it and the part of the husband who died in the common property shall be divided into 3 parts. Indeed, one part was assigned to the husband's family to worship the husband, the two others were assigned to the wife. Generally, this law stipulated the composition of the common property of husband and wife, which consists of three types: husband's property inherited from the family of the husband, property of the wife inherited from the wife's family and the property of spouses that they gathered together during the marriage period. All these assets are under the control of the husband and the head of the family. ${ }^{8}$

The Gia Long Code', however, was supposed to have a setback in terms of the matrimonial property relationship between spouses, which "almost copied the full text of the Manchu Law of China". ${ }^{10}$ By the time Vietnam was measured by the Chinese, Vietnam had to apply the feudal laws of the Chinese dynasties. The Chinese dynasty at that time promoted the patriarchalism and Confucianism as a precept for behaviour in social and family relations. ${ }^{11}$ The Gia Long Code as well as the Chinese law at that time did not regulate the marriage property relation, because marriage' only job was to bring the wife into the husband's family. In addition, the Gia Long Code tended to implement the complete dependence of the wife on her husband's family.

\footnotetext{
${ }^{4}$ VŨ VĂN, Cổ luật Việt Nam lược khảo 82-83.

${ }^{5}$ VĂN, Thời dại Hùng Vương 121.

${ }^{6}$ PHAN ĐĂNG - TRƯƠ'NG THỊ, Các chế độ hôn nhân và gia đình Việt Nam xưa và nay 8-12.

${ }^{7}$ The Hong Duc Code (also known as the Penal Code of the Le Dynasty) was compiled several times in the years 1470

- 1497 under King Le Thanh Tong of the Le dynasty. See VŨ VĂN, Cổ luật Việt Nam và Tư pháp sử 195

${ }^{8}$ HÀ NHƯ, Chế độ hôn sản pháp định trong luật Việt Nam 3.

${ }^{9}$ Gia Long Code (also known as Hoang Viet Luat Code) was issued in 1812 under King Gia Long of Nguyen Dynasty. See VŨ VĂN, Cổ luật Việt Nam và Tư pháp sử 205

10 See HÀ NHƯ, Chế độ hôn sản pháp định trong luật Việt Nam 35.

${ }^{11}$ From the time of $V$ an Lang state formation to The Feudal period, religion and belief in Vietnam was not formed clearly. Mostly Vietnamese people worship animals such as To-Tem birds to pray for good agricultural activities. See VĂN, Thời đại Hùng Vương 229.
} 
Thus, regardless of the point of view, the nature of the Feudalism reflects the nature and structure of the feudal society, where the law is too backward, with customs and practices. Poorly developed from centuries ago, it was gradually ingrained into the subconscious of each and every person, and the legal documents promulgated by the State were based on that customs. Therefore, the law of Marriage and Family under the Feudalism was a protection tool for the feudal landlord and always protected the interests of the husband. Ownership of the common property of husband and wife, first focusing on the husband and the head of husband's family. There was not a real equality between wife and husband in the personal relations and property of the wife.

\section{$-24-$}

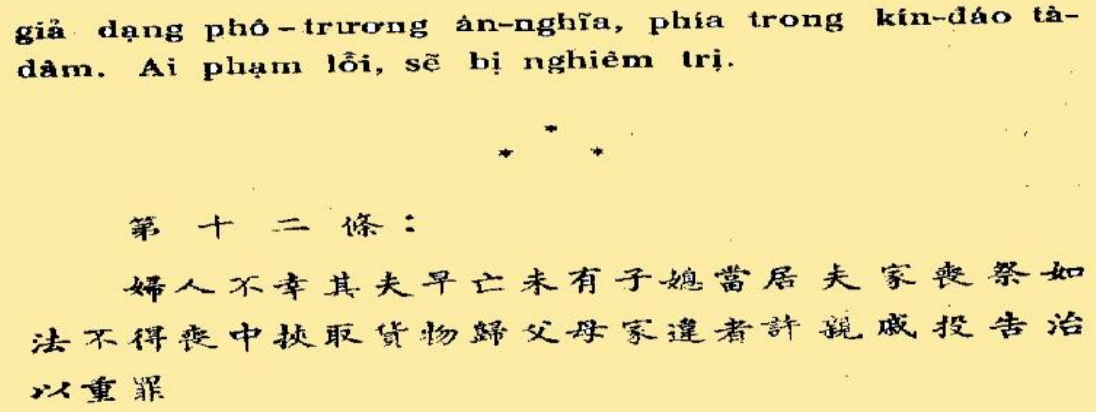

Figure 1. Le Trieu' the Law - 47 Regulations of Laws educating residents under The Le Dynasty

Specifically, that figure 1 is taken from Article 12 of the 47 Regulations of Laws educating residents under the Le Dynasty and the period of application of these laws was July 1663 to $1760 .{ }^{12}$ Based on Article 12, Article 13 of the 47 Regulations of Laws educating residents under the Le Dynasty, we find that a women depended almost entirely on her husband's family. For example, even when the husband died, they should have stay with their husband's family, took care of their

\footnotetext{
12 TRẦN VĂN, Lê Triều giáo hóa Điều Luật 21.
} 
children (including the husband's own children) and should not have brought any husband's property to their parents' home. This law shows that women at this stage had no property of their own. The property that they had during the marriage period belonged to the husband. When the husband died, the property belonged to the husband's family.

\section{The matrimonial property regime during the French colonial period (from 1858 to 1945)}

When the French invaded Vietnam, they applied the provisions of the Civil Code of France Napoleonic Code of 1804 to Vietnam to manage and easily govern as their own. In fact, France divided Vietnam into three regions for easy governance and management. So, at that moment, Vietnam had three sets of laws: in the north, in the middle and in the south. France introduced the Civil Code in 1883 (as known as Précis de 1883) applied in the south and the three big cities of Hanoi, Hai Phong and Da Nang. In addition, France issued the Northern Civil Code in $1931^{13}$ in the North and the Civil Code in $1936^{14}$ applied in the Middle.

Property regimes between spouses were defined in the Civil Code of the North and the Civil Code of the Middle were community property regimes, but the patriarchal authority was assigned to the husband in the family. In addition, according to the Civil Code of the North in 1931, there had been a progressive regulation on contractual property between husband and wife. "In terms of property, the law only interfered with the property of husband and wife when husband and wife had no marriage contract. If the marriage contract was not contrary to the fine customs and not contrary to the interests of the busband was advocated in the union". ${ }^{15}$ These regulations had many similarities with the French Civil Code 1804. Specifically, the French matrimonial property law ${ }^{16}$ was defined from Articles 1389 to 1421 in Title V of the contract of marriage and the respective rights of spouses. Accordingly, the couple had two property regimes to choose from: a community property (including movable and immovable properties which were acquired during the marriage - Article 1401) or dowry property (can be understood as a separate property regime). However, the dowry property only applied when the couple had an agreement before marriage. Thus, the community property law would automatically apply if the couple had no property agreement. In addition, Articles 1421 and 1428 of the French Civil Code stipulated that only the husband had the right to manage the community property of the spouses and even the separate property of the wife.

Under the Civil Code 1936 in the Middle of Vietnam stated: "If the husband and the wife had no agreement, the property of the husband and wife was incorporated into the community of property, that is, the gains from the property of the husband and wife united into one". ${ }^{17}$ Although spouses may have their separate properties from before marriage and during the marriage period, those properties including both

\footnotetext{
13 This law was issued on 30 March 1931 and applied from 1 July 1931 in the North of Vietnam. See HÀ NHƯ, Chế độ hôn sản pháp định trong luật Việt Nam 39.

14 This law was issued on 13 July 1936 and applied to the Middle of Vietnam.

15 Article 104 of the Northern Civil Law of 1931. In addition, Bui Minh Hong also mentioned in detail the marriage contract in the law at this time. At the same time, the author compared French law. View source: Bùi MiNH, Chế độ tài sản theo thỏa thuận của vợ chồng liên hệ từ pháp luật nước ngoài đến pháp luật Việt Nam Source from https://thongtinphapluatdansu.edu.vn/2010/01/05/4322-2/ [accessed 2018/10/10].

${ }^{16}$ Decree dated 10 February 1804 and promulgated the $20^{\text {th }}$ of the same Month in France.

17 Article 105 Civil Code in Middle 1936.
} 
movable and immovable properties were merged into community property of husband and wife. However, those were a temporary union during the marriage. Only the property created by the couple during the marriage was the official community property. When the marriage was terminated, the separate properties of the spouses which had been temporarily merged into the common properties would set back into separate properties. Then, the husband and wife were entitled to take back their separate properties.

In the South, Civil Code in 1883 did not provide specific information on the property regime between husband and wife. This Civil Code only analyzed the effect of marriage on the parties to the marriage without mentioning the property between them. There was a complete lack of regulations on matrimonial property until the Family Law dated 2 January 1959 by the Democratic Republic of South Vietnam ${ }^{18}$. Thus, in order to resolve property conflicts between spouses during this period, "the judges relied entirely on the provisions of the Gia Long Code and the case law". ${ }^{19}$

Although the Civil Code in the North and the Civil Code in the Middle had some new advances in regulating property regimes between spouses, the property regime between husband and wife shows inequality between men and women, as well as between husband and wife in the family.

Again, at this stage, the law of marriage and family in Vietnam was heavily influenced by the French law and conceded the regime of property under the marriage (agreement). However, at this point, people were poor, underdeveloped, and under the oppression and exploitation of French colonialism. The idea of taking out the property to agree before the end was not of interest to couples. There might have been some Frenchmen who married Vietnamese women to think of the property regime under the agreement, to protect their interests when they divorced. In general, the property regime between husband and wife under the agreement in this period had not been the lawmaker's interest, so there were no specific regulations or guidelines, but only a general way. Husband was still legally protected in family property.

In general, matrimonial property regime in this period was a mixture of feudal law and French law. By combining parternal legal thinking with the ideas of Western jurisprudence, colonial lawmakers built the concept of the couple's property regime using terms borrowed from French law namely community property, separate property and asset management. It should be noted that property relations between spouses were governed by French legal norms in the legal systems in the North and the Middle of Vietnam. In the South of Vietnam, there was no system of rules governing the relations of matrimonial property between husband and wife.

\section{Property regime between wife and husband from the August Revolution in 1945 succeeded to date (from 1945 to present)}

In the period of 1945, Vietnam was divided into northern and southern parts. In the North, the success of the August Revolution in 1945 enabled the north of Vietnam to achieve independence

\footnotetext{
${ }^{18}$ See part 3 of this article.

${ }^{19}$ NGUYỄN NGỌC, Giáo trình Luật Hôn nhân và gia đình Việt Nam 4.
} 
and socialist development under the influence of Marxism-Leninism ${ }^{20}$. In the North, the Family Law Act of 1959 regulated the matrimonial relationship of property between husband and wife. In contrast, in the south of Vietnam, laws developed under the influence of the Democratic Republic and Family Law dated in January, $1959^{21}$ were applied in the South to regulate matrimonial property relations between husband and wife.

In the North, the Law of Marriage and Family in $1959^{22}$ issued by the State had confirmed the nature of socialist law. Remarkably, on 10 July 1959 the Supreme Court issued a Directive No.772 /TACD to suspend the application of colonial and feudal law. From that point on, the North lacked a Civil Code. Therefore, the regulation of property relations between husband and wife were only recognized in the Family Law 1959. In 1995, Vietnam promulgated a new Civil Code after the independence and unification of the nation since 1975. The Marriage and Family Law 1959 only provided for common property between husband and wife, which was the statutory property law. The law stipulated that spouses had the right to own, enjoy, and use the same property before and after marriage. ${ }^{23}$ This stipulated that all the property of husband and wife before or after marriage was in the community property. Whenever a spouse had a personal or inherited estate, all the properties were in the property of both spouses, irrespective of the source of the property and the contribution. The law did not recognize spouses having separate property. Specifically, Article 28 on the Family Law 1959 provided that "when a busband and wife divorced, they forbad the reclaim of their private property". It could be said that legislative level in this period was sketchy due to the wars and the idea of abolishing regulations built by the French and Feudal colonies. Therefore, it was not possible to find the concept of marriage property regime that was used to regulating in the Civil Code in the North and in the Middle previously.

In the South, after 1954, the USA replaced the French colonialists in the war of aggression. During this period, legal issues regulating marriage and family relations under the Democratic Republic politics were reflected in three legal documents: Family Law (dated 2 January 1959), Law No. 15/1964 (dated 23 July 1964) ${ }^{24}$ and the Civil Code 1972, envisaged that the community of movable and immovable property would be the legal property regime applicable to spouses. Specifically, the Civil Code of $1972^{25}$ stipulated: spouses can freely make marriage contracts at their will, but not against the public order and fine customs. ${ }^{26}$ In addition, the law

\footnotetext{
${ }^{20}$ The Marxism-Leninism point of view generally promotes the role of the monogamous family, highlights the role of equality and protects the legitimate interests of women. See HÀ HoÀng, Quan điểm của chủ nghĩa Mác - Lênin về gia đình và vận dụng xây dựng gia đình văn hóa ở Việt Nam 168. Source from http:/ / tapchidantoc.ubdt.gov.vn/201506-09/744df70048ada0fdbe53beeacb721bf3-cema.htm [accessed dated 2018/10/30].

${ }^{21}$ Family Law No. 1/59 dated 1 January 1959 enacted by The President (Ngô Đinh Diệm) of Democratic Republic in the South of Vietnam.

${ }^{22}$ Law No. 2/1959/QH, dated 29 December 1959 of The National Assembly on Marriage and Family which was applied to The North of Vietnam.

${ }_{23}$ Article 15 in The Marriage and Family Law 1959 (Law No. 2/1959/QH, dated 29 December 1959 of The National Assembly on Marriage and Family which was applied to The North of Vietnam).

24 This law was replaced Family Law dated 2 January 1959 in the South.

${ }_{25}$ Pursuant to Law No. 028 TT / SLU dated 20 December 1972 by the president of the Democratic Republic of Vietnam.

${ }^{26}$ Article 144 the Civil Code of 1972.
} 
provided that statutory property regimes were applicable only when spouses have no agreement to establish a marriage contract. ${ }^{27}$

Thus, under the socialist regime in the North Vietnam, the husband and wife only existed in common property and they had equal share in this community property. Under the Democratic Republic in the South Vietnam, there were two models of property regime namely the community property regime and the contract of marriage. In April 1975, South Vietnam was completely liberated, and the country was united from North to South. ${ }^{28}$ The political system from this time onwards was the Socialist Republic of Vietnam. From 1975 to 2018, Vietnam has been undergoing three major regulations on property regime between husband and wife. Specifically, the Law on Marriage and Family in 1986, ${ }^{29}$ the Marriage and Family Law in $2000^{30}$ and the Law on Marriage and Family in 2014.

However, there was a major limitation in the 1959, ${ }^{31} 1986$ and 2000 Family Marriage Law, namely, that they did not regulate the property regime under the marriage contract. Specifically, these laws only recognized the statutory property regime. In the statutory property regimes, spouses have both common property and separate property. According to Article 27 of Marriage and Family Law 2000, common properties of husband and wife were as followed. 1, property created by husband and wife, incomes generated from labor, production and business activities and other lawful incomes of husband and wife during the marriage period; property jointly inherited or given to both, and other property agreed upon by husband and wife as common property. 2 , the land use right obtained by husband and wife after their marriage is their common property. The land use right obtained before the marriage or personally inherited by husband or wife shall be common property only if so agreed upon by husband and wife. 3, where there was no evidence proving that a property being in dispute between husband and wife is his/her personal property, such property was common property. According to Article 32 of Marriage and Family Law 2000, separate properties of husband and wife were the following: property owned by each person before their marriage; property inherited/or given separately during the marriage period; property separately divided to husband or wife under division of common property during the marriage period; personal belongings and jewelry.

Then, the Law on Marriage and Family in 2014 came into force in Vietnam ${ }^{32}$ and has now overcame this limitation. Indeed, the Marriage and Family Law of $2014^{33}$ stipulates that spouses have the right to choose a statutory property regime or agreed property regime (also known as a marriage contract) at the time of their marriage. "If married couples do not have an agreement on marriage contract, the statutory property regime will automatically be applied. ${ }^{134}$ However, the establishment of a marriage contract must be established prior to marriage and shall not be established after

\footnotetext{
${ }^{27}$ Article 45 The Family Law in the south and Article 145 the Civil Code of 1972.

${ }_{28}$ The Democratic Republic in the South Vietnam was collapsed completely.

${ }^{29}$ Law No. No. 21-LCT/HDNN7, dated 29 December 1986 of The National Assembly on Marriage and Family.

${ }^{30}$ Law No. 22/2000/QH10, dated 19 June 2000 of The National Assembly on Marriage and Family.

31 The Family Law in the North was issued and recognized by Socialist Republic of Vietnam.

32 This law takes effect on 1 January 2015 in Vietnam.

${ }^{33}$ Law No. 52/2014/QH13, dated 19 June 2014 of The National Assembly on Marriage and Family, gazette number 52/2014/QH13.

34 Article 7 of Decree No. 126/2014/ND-CP dated 31 December 2014 by The Vietnam's Government. This Decree is detailing a number of Articles and Measures for implementation of the law on Marriage and Family 2014.
} 
marriage. During the marriage period, couples are entitled to switch from a marriage contract to a statutory marriage. Conversely, couples who are applying a statutory property regime can not be transferred to a marriage contract after marriage. Explaining this rule, lawmakers argued that the choice of the statutory property regime was that spouses could still agree to split their common property and convert it into their separate property. In contrast, they may agree to merge separate property into common property during the marriage. In addition, this contributes to the difference from the contract of marriage, the agreement model must be established before marriage and can not be established after marriage.

Compared with the Hungarian legislation on marriage, there are two property regimes that couples are allowed to choose when establishing a cohabitation relationship: the statutory property regime and the property regime as agreed (also known as a marriage contract). With respect to the statutory property regime, there are two main types of property that are community property and separate property. As for the marriage contract, couples can agree at any time during the marriage process and the validity of the marriage contract is calculated from the time they are established agreements. ${ }^{35}$ This is considered a progressive difference compared to Vietnamese law. Unlike the law of Vietnam, Hungarian law does not limit the time of establishing a marriage contract to prior to marriage. The limitation of the time of establishing a marriage contract in Vietnamese law limits the will to establish ownership of the couple. This is considered to be the regulation that Vietnamese law should learn from Hungarian law. In general, Marriage and Family Law of Vietnam has had a great deal of regulations which have improved considerably until now. However, there are still some limited rules that should be learn from other countries' legislation and Hungary is an excellent model.

\section{Bibliography}

BÙI MINH Hồng: Chế độ tài sản theo thỏa thuận của vợ chồng liên hệ từ pháp luật nước ngoài đến pháp luật Việt Nam (Property regime as agreed between husband and wife related from foreign law to Vietnamese law): Journal of Law No. 11/2009 Source from https://thongtinphapluatdansu.edu.vn/2010/01/05/4322-2/ [accessed dated 2018/10/10].

ĐINH GIA Trinh: Sơ thảo lịch sử nhà nước và pháp quyền Việt Nam (A brief history of the state and rule of law in Vietnam). Volume 1, Hanoi 1988

HÀ HoÀNG Giang: Quan điểm của chủ nghĩa Mác - Lênin về gia đình và vận dụng xây dựng gia đình văn hóa ở Việt Nam (The Marxism-Leninism view of family and the use of cultural families in Vietnam). Ethnographic Journal 12/2014, No. 168. Source from http://tapchidantoc.ubdt.gov.vn/2015-06-09/744df70048ada0fdbe53beeacb721bf3cema.htm [accessed dated 2018/10/30].

HÀ NHƯ Vinh: Chế độ hôn sản pháp định trong luật Việt Nam (The legal marriage regime in Vietnamese law). Saigon 1967

NGUYỄN NGọC Điện: Bình luận khoa học Luật hôn nhân và gia đình Việt Nam (Science commentary Law of marriage and family in Vietnam). Young Publishers 2004

\footnotetext{
35 4:63, Clause 1 in Hungarian Civil Code 2013 - Book Four (Family Law) prescribes that: "(1) The function of the marriage contract is to permit the parties to the marriage or the spouses to define a property regime - in lieu of marital community of property - with a view to governing their property relationships during the marriage from the time specified in the agreement (...)".
} 
NGUYỄN NGọC Điện: Giáo trình Luật Hôn nhân và gia đình Việt Nam (Course Book- Law on Marriage and Family Vietnam). Volume 2, Cantho 2006

PHAN ĐĂNG Thanh - TRƯớNG THỊ Hòa: Các chế độ hôn nhân và gia đình Việt Nam xưa và nay (The old and new Vietnamese marriage and family regimes). Ho Chi Minh City 2012

PHAN HuY Chú: Lịch triều hiến chương đại chí (The encyclopedia in Vietnam). Book One, Vietnamese Historical Institute 1960

VAN Tan (Editor): Thời đại Hùng Vương (Hung Vuong Age). Hanoi 1976

VŨ VĂN Mẫu: Cổ luật Việt Nam lược khảo (Vietnam Law Review). Book One, Saigon 1971

VŨ VĂN Mẫu: Cổ luật Việt Nam và Tư pháp sử (Vietnamese Law and Judicial History). Book One, Saigon 1973 